\title{
The Ability to Pay and Willingness to Pay on Operation of Adi Soemarmo Airport Train Access Line to Airplane Passengers
}

\author{
Wahyu Chrismasto*, Imam Muthohar, Danang Parikesit \\ Universitas Gadjah Mada, Yogyakarta, INDONESIA \\ Jalan Grafika No 2 Yogyakarta \\ ${ }^{*}$ Corresponding authors: w4hyu2001@yahoo.com
}

SUBMITTED 1 August 2019 REVISED 28 October 2019 ACCEPTED 26 November 2019

\begin{abstract}
Connectivity between transportation nodes is crucial in encouraging the movement of people and goods, including access to Adi Soemarmo Airport. Currently, access to Adi Soemarmo Airport is dominated by private vehicles and taxis compared to public transportation such as buses which can be costly for some passengers. To cut the cost of transportation in Adi Soemarmo airport, the Ministry of Transportation has built railway access to Adi Soemarmo Airport from Solo Balapan Station and vice versa. However, the scheme of train's tariff is solely designed to accommodate only operational and maintenance cost, while the ability and willingness of passengers to pay are simply neglected. This research aims to analyse willingness to pay of airplane passenger for the operation plan of airport train based on mode choice model and contingent valuation method and finally be able to determine the tariff based on willingness to pay and train operating costs. Mode choice model uses logit binomial in terms of differences with a stated preference method, willingness to pay analysis uses the net economic value from binomial logit and train operating cost calculations use the Minister of Transportation Regulation Number PM 17 the Year 2018. The average value of willingness to pay of prospective airport train users for each car, taxi and bus users based on binomial logit model is IDR14,802.42, IDR14,121.13, IDR14,221.42. Meanwhile, the value of the ability to pay for each car, taxi and bus users is IDR60,996.90, IDR79,564.67, IDR55,117.17 and the tariff value based on train operating costs is IDR17,730.22.
\end{abstract}

KEYWORDS Mode Choice; Willingness to Pay; Ability to Pay; Train Operating Costs, Tariff

(c) The Author(s) 2020. This article is distributed under a Creative Commons Attribution-ShareAlike 4.0 International license.

\section{INTRODUCTION}

Currently, Adi Soemarmo Airport serves domestic flights such as Jakarta - Solo PP, Solo - Denpasar PP, Solo - Bandung PP and international flights. Domestic and international passenger movements in 2017 have increased by approximately $27.4 \%$ or have served 2.79 million passengers compared to 2016 which reached 2.19 million passengers (Surakarta, 2018).

One of the problems at Adi Soemarmo Airport is transportation access to/from the airport. Airplane passengers can use an airport taxi, private cars, Batik Solo Trans buses to get to/from the airport. However, private car and taxi use look more dominant than Batik Solo Trans (BST) buses.
To overcome this problem, the Ministry of Transportation has built railway access to Adi Soemarmo Airport from Solo Balapan Station. The airport railway line was built with the main station at Adi Soemarmo Airport by PT. Angkasa Pura I and at Solo Balapan Station and additional new stations namely Kadipiro Station by the Ministry of Transportation. It is expected with the operation of the airport railway line to Adi Soemarmo Airport then airplane passengers get a good alternative in travelling to/from Adi Soemarmo Airport.

Operational dan maintenance cost is the main component in the determination of tariff. Currently PT. KAI (Persero) has operated a train 
namely Solo Ekspres with a service route Solo Balapan Station-Kutoarjo Station with a tariff IDR40,000. The train will be operated to serve airplane passengers to/from Adi Soemarmo Airport later. According to PT. Raillink (2018) occupancy ratio of airport trains that have operated in advance namely Airport Railway Soekarno-Hatta Airport has only reached 30\% (2500 pax/day from its capacity 11,000 pax/day) with the tariff IDR70,000. Lower occupancy is potentially due to tariff was considered to be expensive for the majority of the passengers. Therefore, it is vital for transportation service providers to consider the ability and willingness of passengers to pay for transportation services so that transportation services can be utilised maximally for people who use transportation services.

The objectives of the research are to analyse willingness to pay of airplane passengers for airport train and finally a recommendation of airport train tariff can be proposed based on willingness to pay and train operating costs (BOKA).

The research is located on Adi Soemarmo Airport Train, where the train line is still under construction. Prospective passengers of Adi Soemarmo Train are airplane passengers at Adi Soemarmo Airport, train passengers at Solo Balapan Station and Klaten Station who have used airplanes through Adi Soemarmo Airport. Primary data collection is using stated preference method and secondary data in the form of train operating costs (BOKA) was obtained from Directorate General of Railways, Ministry of Transportation Republic of Indonesia.

\section{LITERATURE REVIEW}

\subsection{Characteristics of Mode Choice to the Airport}

Past studies have conducted research related to variables that influence mode choice for airplane passengers to airport. Setiawan (2017), Wulansari (2016), and Wulansari et al.(2015) stated that tariff is the most dominant factors to be considered by the passengers in selecting transportation mode. Tariff is more considered compared to other variables such as travel time, integrated ticket system, frequency/headway and excellent facilities on the train. Research conducted by Tsamboulas, Evmorfopoulos and Moraiti (2012) found that the most important variables affecting the selection of transportation modes for airport workers at Athens International Airport are the total travel cost, travel time and income of transportation services users. Train departure schedules, station check-in systems and tolerance of train delays are some factors affect the selection of transportation mode (Fitriatmaja \& Dewanti, 2015). In contrast , research by Jou, Hensher \& Hsu (2011) at Taiwan's Taoyuan International Airport stated the important factors that influence transportation mode are travel time outside the vehicle and travel time in the vehicle. Ridwan et al. (2018) mention the availability of train accessibility to the strategic location and passenger security affect the willingness of passengers to use train. Gosling and ASCE (1986) found that long walking distances and the need to negotiate stairs or turn-stiles will create problems for passengers with baggage and will discourage passengees use of train. In fact, space for baggage during peak hours and passengers safety are the fundamental factors for the selection of transportation mode. Safety is a factor that particularly selected by business travelled passengers. They usually prefer to arrive early to the airports to avoid missing their flight (Gokasar \& Gunay, 2017)

\subsection{Determination of Tariff}

Peraturan Menteri Perhubungan Nomor PM 17 Tahun 2018 explains that in calculating basic costs for transportation service businesses, especially trains, there are several components that need to be considered in determining train tariffs including capital costs, fixed direct costs, not fixed direct cost, fixed indirect costs, not fixed indirect cost and maintenance costs.

In addition to the determination of tariffs based on the regulations above it is also necessary to consider ability to pay and willingness to pay for transportation service users because ability to pay 
and willingness to pay will affect the level of usage of transportation services.

According to Tamin et al. (1999) several factors influence ability to pay (ATP) such as income per month, transportation needs, total transportation costs, travel intensity, monthly expenses, type of activity, percentage of income used for transportation costs. Meanwhile willingness to pay (WTP) is influenced by several factors such as the production of transportation services provided by service provider, the quality and quantity of services provided by service provider, the utility of users of public transportation and the income of service users.

Furthermore the determination/adjustment of tariff is recommended as follows:

a. Not exceed ability to pay value.

b. If the tariff is between ATP and WTP, the level of services can be adjusted.

c. If the proposed tariff is lower than the tariff calculation, but more than ATP, then the difference can be considered as a subsidy that must be borne by the government as a regulator.

d. If the calculation of tariffs is far below ATP and WTP, there is flexibility in calculating the value of the new tariff, which can be used as an opportunity for the implementation of cross subsidies on other types of vehicles that have a tariff calculation above ATP.

\section{THEORITICAL FRAMEWORK}

\subsection{Stated Preference Method}

In conducting the preference survey, there are two approaches, namely revealed preferences and stated preferences. The first method is revealed preference, this technique analyzes the choice of respondents based on conditions that already exist in the field. This technique has several disadvantages in terms of estimating the response of respondents to new options not yet available (Ortuzar \& Willumsen, 2011).

According to Aizaki, Nakatani, and Sato (2015) and also Ortuzar and Willumsen (2011) stated preference is a survey method to measure respondents preferences in giving decisions in situations of alternative choices in the form of a hypothesis, so this survey can include more attributes and conditions than in the field. The alternative option selected by respondents can be goods, policy options, travel modes and others.

Bateman, et al. (2002) and Kjaer (2005) as quoted in Accent \& Europe (2010) added that stated preferences can be used to determine preferences related to costs. Choice modeling techniques can be grouped into four categories that describe differences in assumptions, analytical methods and experimental design procedures. In the discrete choice method, respondents choose one alternative from two or more alternatives provided. Each respondent might be asked to repeat the option repeatedly using different attribute levels according to the experimental design. In contrast to the contingent ranking, respondents must provide a rating of all alternative options offered. Contingent ranking can also be approached as a sequential selection process where the first time respondent is asked to select the most preferred alternative from the total $\mathrm{N}$ alternatives, then the selected alternative is omitted from the given choice and the respondent is asked to choose the most preferred option from the option $\mathrm{N}-1$. On the contingent rating, respondents are presented with one alternative at a time and are asked to rate each separately on a semantic or numeric scale. Each respondent can rank a series of alternative options with varied attribute values. The level of complexity of the contingent rating is higher than contingent ranking or discrete option because the respondent must provide an assessment.

The last method of choice modeling techniques is pair comparisons, in this method respondents are asked to choose the alternative they like from a series of two choices and respondents are asked to show the strength of their preferences on a numerical or semantic scale. This method is a combination of discrete choice and contingent rating, where the respondent is not only asked to choose the most preferred alternative but also asked to assess the strength of his choice. 
Contingent valuation is one of the stated preference methods where respondents are asked to provide monetary valuation of the benefits of an item or service that has been obtained. This method is grouped into several categories, namely iterative bidding, open-ended, dichotomous choice, payment card. In the iterative bidding method, respondents are asked to answer the willingness to value certain payments for the goods or services offered, if the respondent is willing then it can be continued by increasing the value of the payment to the limit where the respondent is unwilling. In openended, respondents were asked to give a certain maximum value for the goods or services offered, while dichotomous choices of respondents were given a certain monetary value for the goods or services offered and they were asked to answer yes and no. The last method of contingent valuation is the payment card, in this method respondents are asked to choose a certain value for the goods or services provided.

Furthermore, according to Permain and Kroes (1990) respondents preferences can be quantified in several ways as follows:

a. Ranking data (Conjoint measurement) This approach presents all options at once to the respondent, then the respondent is asked to rank the hypothesis option based on his preferences so that he can show the level of utility of that choice

b. Rating data

This method requires a response from the respondent to express his degree of preference for the choices with a certain scale such as a numerical scale or semantic scale, where the scale points are defined by phrases such as "definitely choose $\mathrm{A}=1$ ", "maybe choose $\mathrm{A}=2$ "," Can't choose between A and $\mathrm{B}=3$ "," maybe choose $\mathrm{B}=4$ "," definitely choose $\mathrm{B}=5 \mathrm{~m}$. The five choices are transformed into the form of probability that will be used to create multiple linear regression models.

c. Choice based experiments

In this method the respondent was asked to determine his choice of several alternative choices that have been provided. Options can be added to the option "none of the choices available" to avoid coercive choices.

\subsection{Binary Logit Model}

The binary logit model is used to create mode choice model consisting of only two alternative modes. There are two types of models that are often used, namely binomial logit difference model and binomial logit ratio model. Binomial logit difference equation can be formulated as shown in Equation (1) and (2) (Ortuzar and Willumsen, 2011).

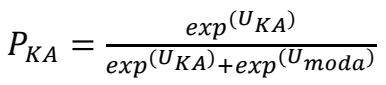

$U_{K A}-U_{\text {moda }}=\operatorname{Ln}\left[\frac{P_{K A}}{1-P_{K A}}\right]$

where $P_{K A}$ is train probability, $U_{K A}$ is train utility, and $U_{\text {moda }}$ is existing mode utility.

The probability of individuals choosing the airport train access mode is a function of the utility difference between the two modes. Assuming that utility functions are linear, the differences in utility expressed in terms of differences in a number of relevant attributes between the two modes are formulated in Equation (3) (Ahmadi, 2011):

$$
\begin{aligned}
U_{K A}-U_{\text {moda }}= & a_{0}+a_{1}\left(X_{1 K A}-X_{1 \text { moda }}\right)+\cdots+ \\
& a_{n}\left(X_{n K A}-X_{\text {nmoda }}\right)
\end{aligned}
$$

where $a_{0}$ is constants, $a_{1}, . . a_{n}$ is coefficient, $X_{1 K A} . . X_{n K A}$ is attribute value of train, and $X_{1 \text { moda,... }} X_{n \text { moda }}$ is attribute value of existing mode. In this study, choice responses are analyzed using point ratings presented on the probability scale to determine the quantitative relationship between attributes by semantic scale, namely $1=$ definitely choose airport train, 2 = maybe choose airport train, 3 = do not know (balanced), $4=$ maybe choose existing mode (private car, taxi, bus), $5=$ definitely choose existing mode (private car, taxi, bus). Semantic scale is transformed into a numerical scale using binary logit transformations, called the Berkson-Theil transform (Sihombing \& Surbakti, 2013). 


\subsection{Ability to Pay and Willingness to Pay}

Calculation of ability to pay (ATP) uses household budget method (Permata, 2012). Ability to pay can be formulated in Equation (4).

$A T P_{\text {umum }}=\frac{I_{t} P_{P} P_{t}}{T_{t}}$

where $I_{t}$ is income per month, $P p$ is percentage of income per month for transportation, and $\mathrm{P}_{t}$ is percentage of income per month for trip to airport , and $T_{t}$ is total length of family trip per month or frequency of travel.

Willingness to pay (WTP) value is obtained from each respondent in the form of the maximum value that the respondent is willing to pay for the airport train tariff that has been offered (Permata, 2012).

$M_{W T P}=\frac{1}{n} \sum_{i=1}^{n} W T P_{i}$

In Equation (5), $M_{w t p}$ is mean of WTP, $\mathrm{n}$ is number of respondent, and $W T P_{i}$ is willingness to pay value of each respondent. Willingness to pay can also be calculated using Equation (6) (Handayani, MHM dan Kusumananti, 2018).

$W T P=P(x) * \frac{x}{d}$

where $P(x)$ is probability of respondent for tariff $x$, $x$ is tariff, and $d$ is distance.

\subsection{Tariff Based on Train Operating Costs}

Train operating costs (BOKA) are costs incurred to operate trains for certain purposes in normal conditions. Calculation of BOKA can be calculated using Equation (7) and (8) (Peraturan Menteri Perhubungan Nomor PM 17 Tahun 2018).

Base tariff $=\frac{(100 \%+\text { profit }) * B P}{(C * L F * d)}$

Distance tariff $=$ base tariff $* d$

where $B P$ is the amount of basic cost, $C$ is capacity, $L F$ is load factor, and $d$ is distance.

\subsection{Significance Test}

Significance test is carried out to find out whether an attribute has a significant influence on the utility equation, one of the significance tests is by $\mathrm{t}$ test and $\mathrm{F}$ test.

\section{RESEARCH METHOD}

\subsection{Study Area}

The study area is located on Adi Soemarmo Airport at Ngemplak Boyolali as shown in Figure 1 below.

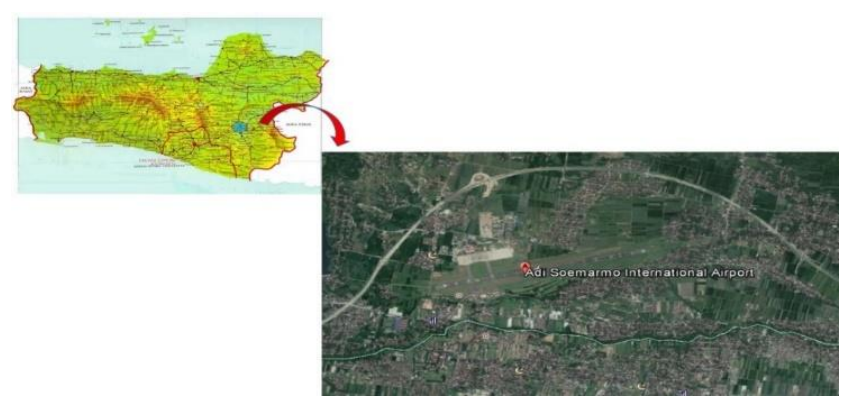

Figure 1. Location map of Adi Soemarmo Airport

\subsection{Survey Method}

In this study, researchers used revealed preference (RP) and stated preference (SP) survey methods through interviews of several respondents, such as airline passengers at Adi Soemarmo Airport for private vehicle users (cars), taxis and buses and train passengers at Solo Balapan Station and Klaten Station that have already traveled using airplanes through Adi Soemarmo Airport.

\subsection{Questionnaire Design}

The questionnaire design consists of several questions, such as characteristics of respondent, mode choice scenario to/from the airport with attribute such as tariff, number of transfers, travel time, and headway, which in each attribute was made with a option level into two levels. The next step is to determine the design of the combination of scenarios that will be used in the main survey, ability to pay (ATP) prospective airport train passengers, willingness to pay (WTP) prospective airport train passengers.

\subsection{Sample Determination and Data Analysis}

Based on Surakarta (2018) and Perhubungan (2011) the average number of aircraft passengers is 2,789 people per day and the proportion of car, taxi and bus users to go to Adi Soemarmo Airport 
is $43.1 \%, 38.7 \%$ and $18.2 \%$ respectively of the total number of aircraft passengers. Whereas the average passenger number of train passengers at Solo Balapan Station is 5,073 people per day, then the sample size can then be obtained.

The sample of car mode users is 98 people, while the sample of taxi mode users is 97 people, the sample of bus mode users is 94 people and the sample at the train station 99 people. The utility difference function is obtained from the results of primary data processing using Microsoft Excel and SPSS 16, then to support the utility function modeling, a correlation test and significance test are conducted whether the binomial logit equation model can be used properly. Furthermore, the sensitivity analysis of the model needs to be done to determine changes in probability values. Ability to pay uses household budget method and willingness to pay uses logit binomial and contingent valuation method and train operating costs (BOKA) using Minister of Transportation Regulation PM 17 Year 2018.

\section{RESULT AND DISCUSSION}

\subsection{Utility Equation}

The estimation results of utility function are as follows:

a. Utility function of airport train and car users $U_{K a}-U_{\text {Car }}=-0,732-0,02753 X_{1}-0,0238 X_{2}$ $-0,0251 X_{3}-0,48851 X_{4}$

b. Utility function of airport train and taxi $U_{K a}-U_{\text {Taxi }}=-0,03123 X_{1}-0,030083 X_{2}$ $-0,02452 X_{3}-0,5597 X_{4}$

c. Utility function of airport train and bus $U_{K a}-U_{B u s}=-0,039642 X_{1}-0,0231 X_{2}$ $-0,02155 X_{3}-0,51319 X_{4}$

where $U_{K a}$ is utility of airport train (AT), $U_{\text {car }}$ is utility of car, $U_{\text {Taxi }}$ is utility of taxi, $U_{\text {Bus }}$ is utility of bus, $X_{1}$ is tariff difference between airport train and existing mode (car, taxi and bus) (IDR), $X_{2}$ is travel time difference between airport train and existing mode (car, taxi and bus) (minutes), $X_{3}$ is headway difference between airport train and existing mode (car, taxi and bus) (minutes) and $X_{4}$ is number of transfer differences between airport train and existing mode (car, taxi and bus) (times).

\subsection{Willingness to Pay}

Based on binomial logit model, the average value of willingness to pay for each respondent of car, taxi and bus users is IDR14,802.00; IDR14,121.13; IDR14,221.42. Furthermore, the willingness to pay analysis will be showed on several groups of respondent characteristics as follows.

a. Willingness to pay based on age

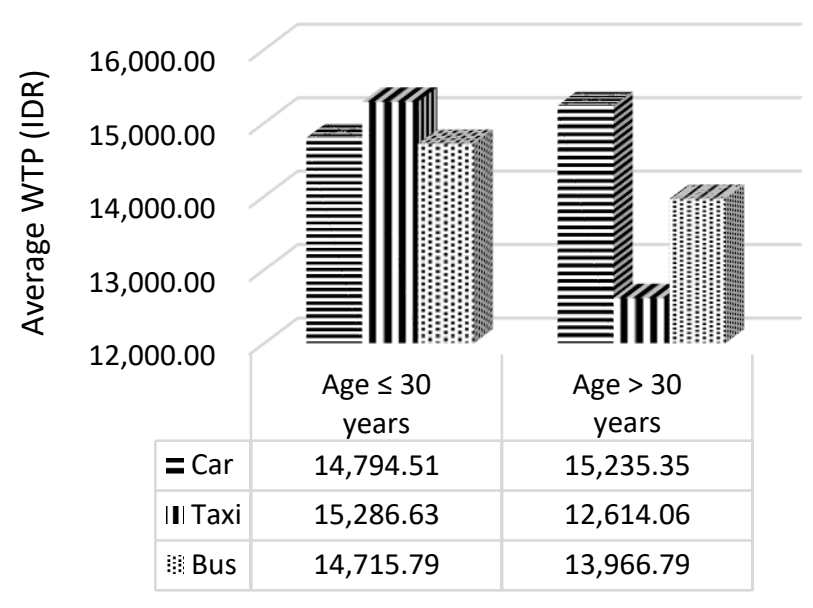

Figure 2. Willingness to pay based on age

Figure 2 shows that the age of respondents $>30$ years, the value of willingness to pay tends to decrease even though the respondents of car users getting increase but the difference between age of $\leq 30$ years and $>30$ years is not too much different. Decreasing of willingness to pay value is likely due to the fact that respondents with age more than 30 years have started to decline in productivity compared to the productivity of respondents with age $\leq 30$ years.

b. Willingness to pay based on travel frequency

Figure 3 shows that the respondents who traveled by airplane more than 2 times/years, willingness to pay value tends to decrease. Decreasing of willingness to pay possibly can be caused by respondents who travel more often will allocate more costs compared to respondent who traveled by airplane less than 2 times/years. 


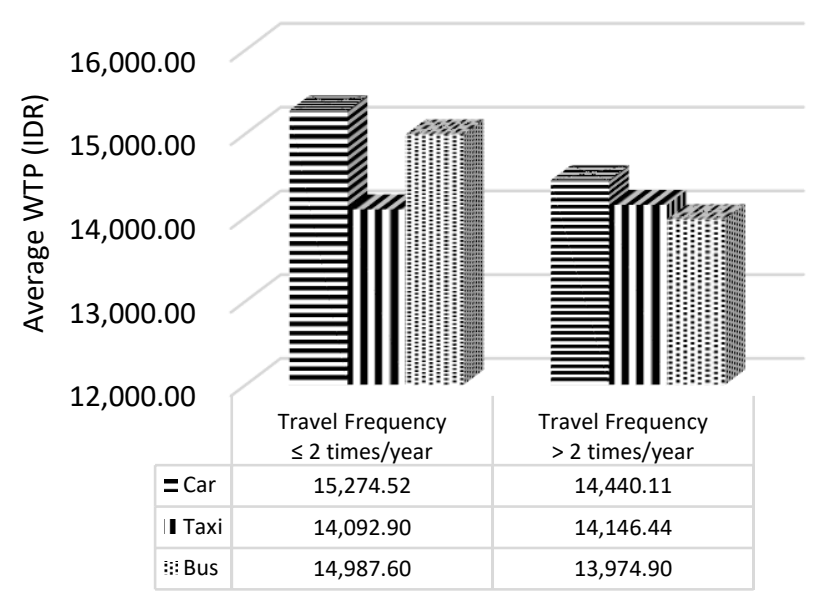

Figure 3. Willingness to pay based on travel frequency

c. Willingness to pay based on the number of dependent

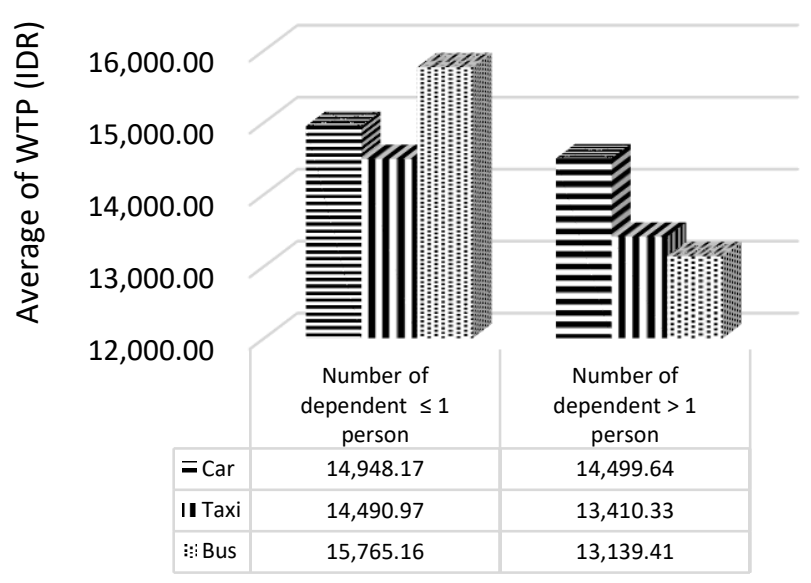

Figure 4. Willingness to pay based on number of dependent

Figure 4 shows that the respondent who have more than 1 dependent then willingness to pay value tends to decrease. Decreasing of willingness to pay possibly can caused by respondents who have more than 1 dependents will allocate more travel cost compared to respondent who have less than 1 dependents.

\subsection{Willingness to Pay Analysis with Contingent Valuation Method}

Based on figure 5 to figure 7 , it can be explained that the sample of respondents of each car user (182 samples), taxis (160 samples) and buses (101 samples) respectively were $51.1 \%$; $51.9 \%$; $62.4 \%$ expect airport train tariff IDR 10,000.00, while the average of WTP value of each respondent using cars, taxis and buses is IDR 18,653.85; IDR. 17,875.00; and IDR. 15,940.59.

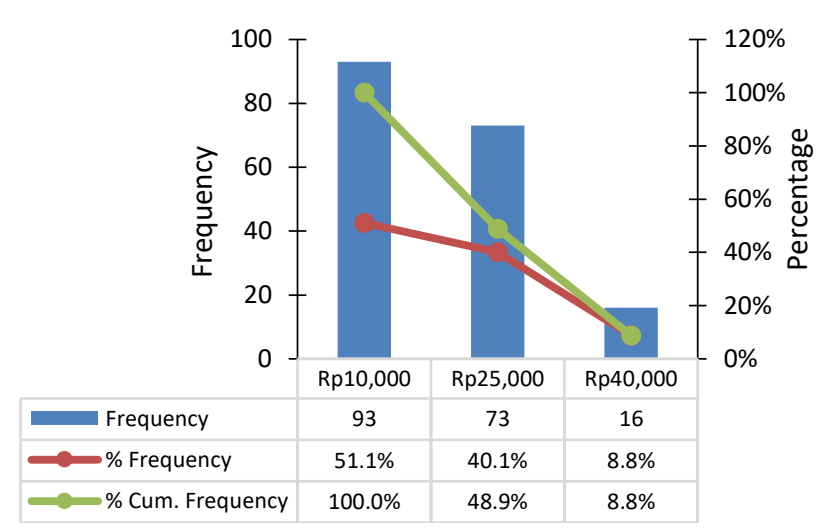

Figure 5. Graph of airport train tariff is expected by car respondents

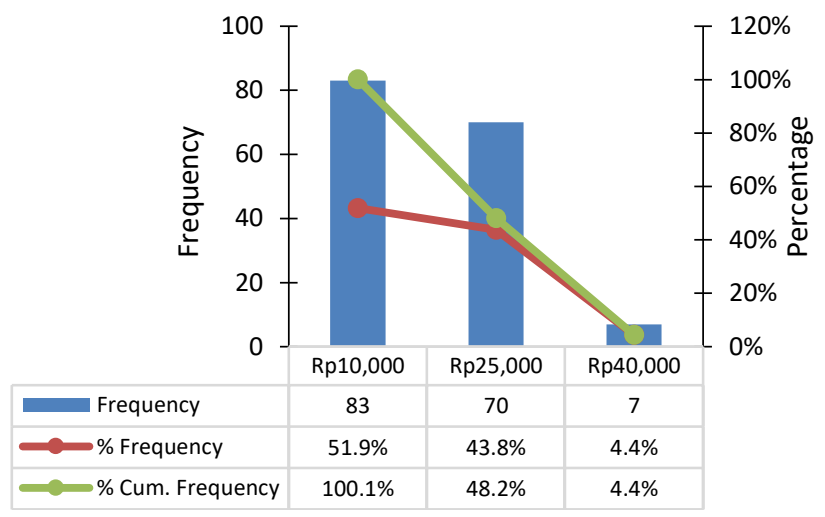

Figure 6. Graph of airport train tariff is expected by taxi respondents

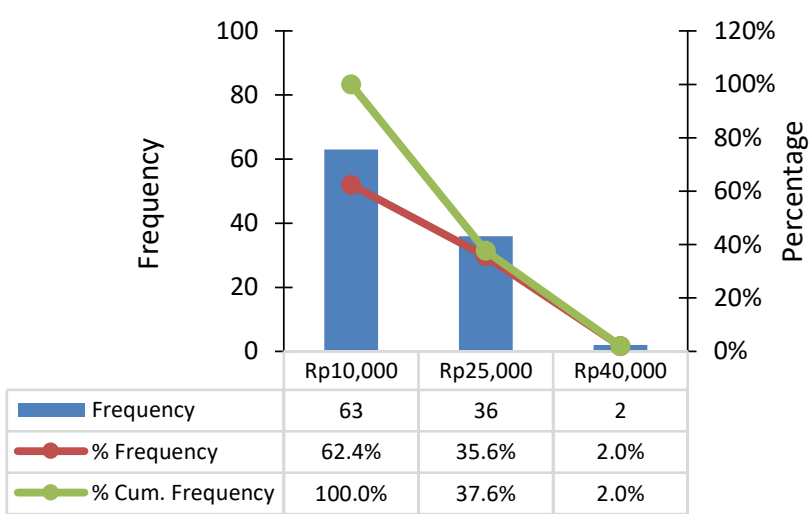

Figure 7. Graph of airport train tariff is expected by bus respondents

\subsection{Ability to Pay}

Calculation of ability to pay based on respondents income, allocation of respondents income for transportation every month, and allocation of transportation costs to/from Adi Soemarmo 
Airport per month, as well as travel frequency to Adi Soemarmo Airport per month. Furthermore, the results of ability to pay (ATP) can be seen in Figure 8 to Figure 10.

Figure 8 to Figure 10 explains that the biggest frequency of ability to pay value of each car, taxi and bus users is located in the range IDR 10,000 IDR29,900 respectively worth $31.8 \%, 32.5 \%$, $38.61 \%$, so if tariff of airport train is set in the range mentioned above, $82.42 \%$ of car users, $86.25 \%$ of taxi users, and $83.17 \%$ of bus users will be able to pay it.

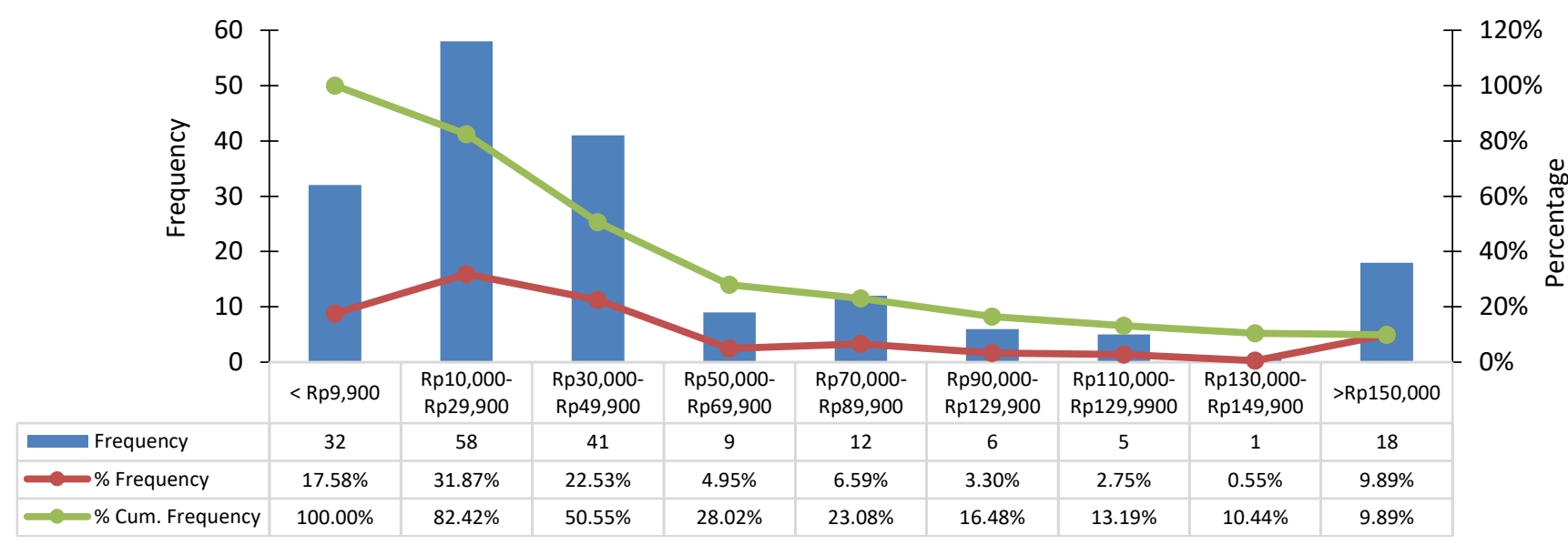

Figure 8 . Ability to pay of car respondents

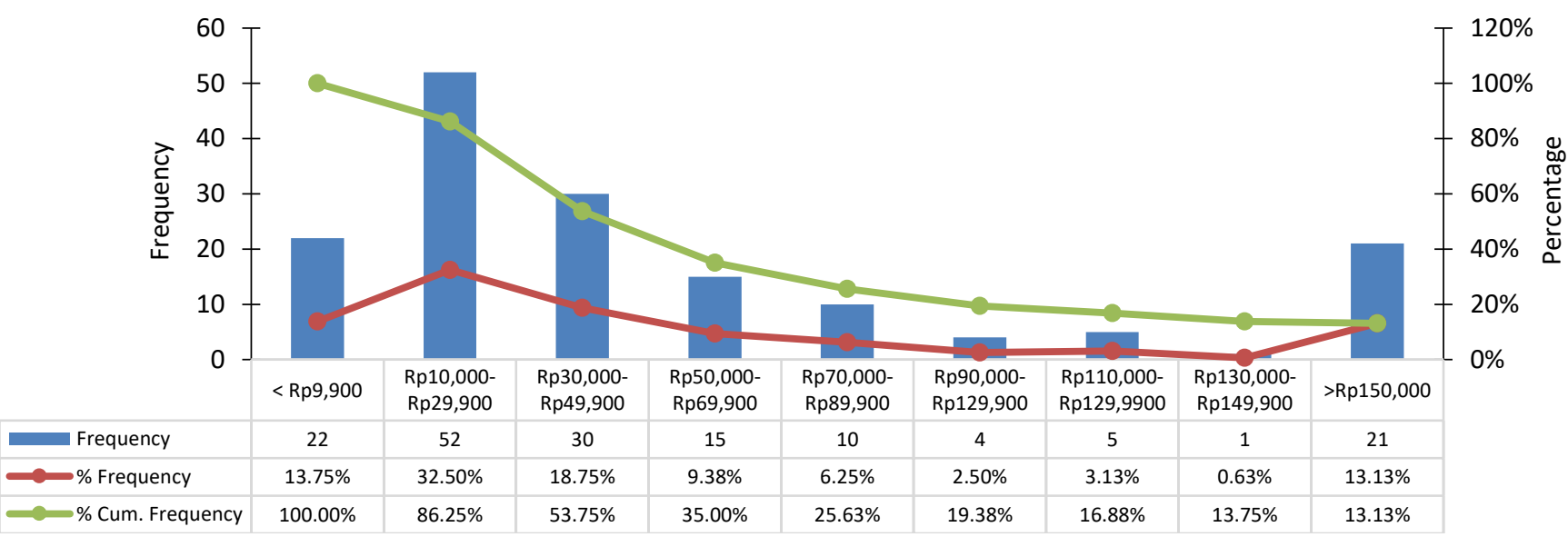

Figure 9. Ability to pay of taxi respondents

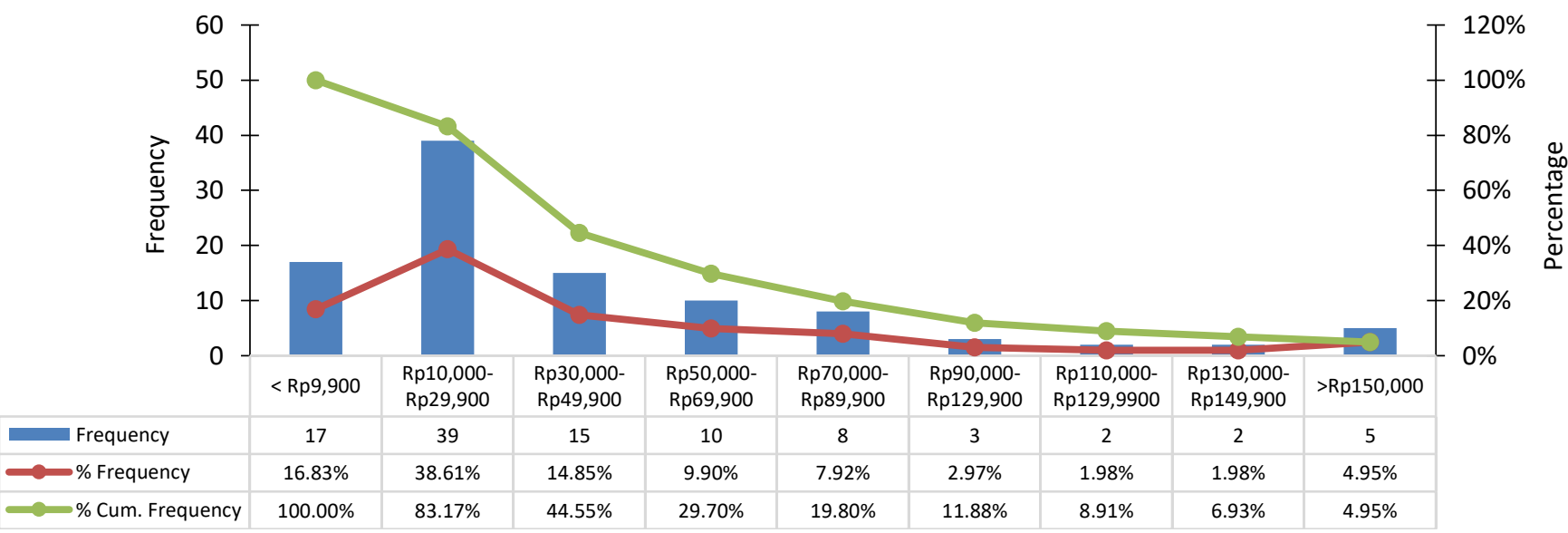

Figure 10. Ability to pay of bus respondents 


\subsection{Train Operating Costs (BOKA)}

Tariff analysis can also be calculated based on train operating costs (BOKA) besides it using willingness to pay and ability to pay approach. Furthermore, the results of tariff based on BOKA for several alternative scenarios can be seen in Figure 11 as below.

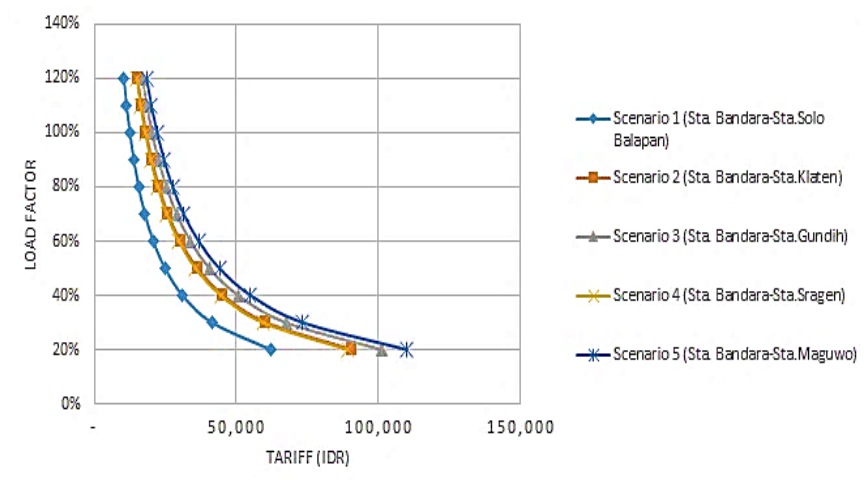

Figure 11. Tariff graph based on BOKA with various services route and load factor

The results of train operating costs are IDR4,434,167.59/lane for scenario 1 with airport train service route Adi Soemarmo Station-Solo Balapan Station. Furthermore, basic tariff can be obtained as much as IDR1313.35/pax.km and distance tariff can also be obtained as much as IDR17,730.22/pax. Whereas for tariff with scenario 2 (airport train service route Adi Soemarmo Station-Klaten Station) can be obtained IDR6,480,127.18/lane and distance tariff can be obtained as much as IDR25,911.09/pax.

\subsection{Tariff Determination}

Figure 12 shows the tariff calculation with four approaches giving varying results, however average WTP value with contingent valuation method is not too much different with train operating costs (BOKA) approaches. Willingness to pay value with binomial logit approach is not much different between car users, taxi users and bus users where taxi users have a lower willingness to pay than car users and bus users, while the willingness to pay value with contingent valuation method for bus users have a lower willingness to pay than car users and taxi users.
The difference between two methods is probably due to respondents can be more sensitive in comparing of services attribute offered in binomial approaches.

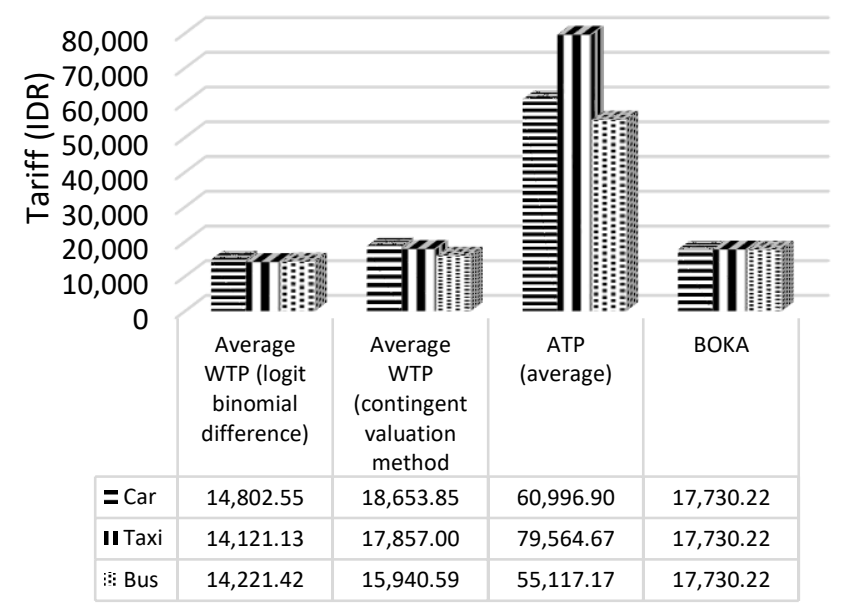

Figure 12. Comparison of tariff calculation

Furthermore, if airport train tariff is set at IDR14,000/pax based on willingness to pay then there is a difference with tariff based on train operating costs (BOKA) as much as IDR3730.22/pax which would be a loss for airport train providers if airport train will be operated from Adi Soemarmo Station-Solo Balapan Station, whereas if airport train is operated with a service route from Adi Soemarmo Station to Klaten Station there is a difference with tariff based on train operating costs as much as IDR11,911.09/pax. However, if tariff difference must be borne by the government so people can use airport train facilities, in one year the government must allocate subsidies (PSO/public service obligation) as much as IDR2,247,726.47 for service route from Adi Soemarmo Station to Solo Balapan Station.

Public service obligation (PSO) is a matter that needs to be considered by the Government and train operators because even though the value of willingness to pay is still less than ATP value, it also needs to be seen how much the utility or service of transportation modes will be offered to respondents and the characteristics of the prospective train user itself. Hidayati (2013) in her research related to the implications of tariff increment in Prameks train Solo-Yogyakarta revealed that tariff increment will be influence 
the loyalty of train users. The tariff increment of Prameks train from IDR10,000.00 to IDR13,000.00 will change the loyalty of commuters become spurious loyalty, meaning that there are still a strong desire to use Prameks train more than $50-75 \%$, but there are a reluctance to use it or in other words commuter don't agree with Prameks train tariff increment. Meanwhile if tariff is raised to IDR25,000.00, then the commuters will become disloyal with percentage of train usage become $<25 \%$. It becomes important how the role of The Government to remain provide support in providing affordable modes of transportation as expected by transportation users.

\section{CONCLUSIONS AND RECOMMENDATION}

Eventhough there are several factors that are considered to select transportation mode, but tarif is the most important among others. Tarifff determination requires prospective passengers participation to express their willingness and ability. This paper presents the tariff determination by considering passengers willingness and ability. Result of this study found that the average value of willingness to pay for each respondent of car, taxi and bus users is IDR14,802.00; IDR14,121.13; IDR14,221.42. Whereas tariff analysis with train operating costs approaches was obtained IDR17,730.22/pax with service route Adi Soemarmo Station to Solo Balapan Station. Therefore, tariff recommendations is IDR14,000.00/pax. By using these calculation, it is expected that the train occupancy will reach $70 \%$.

Further research is needed regarding ticket integration (ticket bundling), both ticket integration between airlines and train operators, ticket between train operators and bus operators in order to increase train users and also using cost benefit analysis (CBA) in determining tariff recommendations.

\section{DISCLAIMER}

The authors declare no conflict of interest.

\section{REFERENCES}

Accent and Europe, R., 2010. Review of Stated Preference and Willingness To Pay Methods. London.

Ahmadi, W., 2011. Analisa Pemilihan Moda Angkutan Penumpang antara KRL Jabodetabek dengan Bus Kota dengan Metode Binomial Logit Selisih (Studi Kasus: Perjalanan Komuter DepokJakarta). Universitas Indonesia.

Aizaki, H., Nakatani, T. \& Sato, K., 2015. Stated preference methods using $R$. Statewide Agricultural Land Use Baseline 2015 .

Fitriatmaja, I. \& Dewanti, 2015. Pengumpan Menuju Bandara Temon ( Studi Kasus : Kereta Api Dan Kendaraan Pribadi ). Bandar Lampung, The 18th FSTPT International Symposium.

Gokasar, I. \& Gunay, G., 2017. Mode Choice Behaviour Modeling of Ground Access to Airports: A Case Study in Istanbul, Turkey. Journal of Air Transport Management, 59, pp.1-7.

Gosling, G.D. \& ASCE, M., 1986. Economic Aspects of Rail Access to Airport. Transport Engineering, 112(2), pp.212-228.

Handayani, D., MHM, A. \& Kusumananti, P.D., 2018. Studi Willingness To Pay Pengguna Jalan Terhadap Tarif Tol Solo-Ngawi (Studi Kasus: Kartasura-Ngawi). e-Jurnal Matriks Teknik Sipil, pp.9-17.

Hidayati, E.M., 2013. Implikasi Kenaikan Tarif Kereta Api Prameks Terhadap Loyalitas Komuter Solo-Yogyakarta. Universitas Gadjah Mada.

Jou, R., Hensher, D.A. \&Hsu, T., 2011. Airport ground access mode choice behavior after the introduction of a new mode: A case study of Taoyuan International Airport in Taiwan. Transportation Research Part E, 47(3), pp.371381.

Kementerian Perhubungan Republik Indonesia, 2011. Studi Kelayakan Pengembangan Akses Kereta Api Menuju Bandara Adi Sumarmo.

Ortuzar, J. de D. \& Willumsen, L.G., 2011. 
Modelling Transport. 4th ed. A John Wiley and Sons,Ltd,Publication.

Peraturan Menteri Perhubungan Republik Indonesia Nomor PM 17 Tahun 2018 tentang Pedoman Tata Cara Perhitungan dan Penetapan Tarif Angkutan Orang Dengan Kereta Api.

Permain, D. \& Kroes, E., 1990. Stated Preference Techniques:A Guide To Practice. Den Haag: Steer Davies \& Gleave Ltd and Hague Consultancy Group.

Permata, M.R., 2012. Analisa Ability To Pay Dan Willingness To Pay Pengguna Jasa Kereta Api Bandara Soekarno Hatta - Manggarai. Universitas Indonesia,

PT. Raillink, 2018. Okupansi Kereta Bandara Baru $30 \%$, Dirut Railink: Malaysia Saja Butuh 8 Tahun Capai Target, Jakarta : Okezone

Ridwan, U., Priyanto, S. \& Suparma, L.B., 2018. Analisis Ability To Pay ( ATP) dan Willingness To Pay ( WTP ) Pengguna Sepeda Motor , Mobil Pribadi dan Bus di Wilayah Yogyakarta dan Bantul terhadap Pengoperasian Kereta Api Perkotaan. Jurnal Riset Daerah, XVII(1), pp.2941-2971.

Setiawan, D., 2017. Analisis Pemilihan Moda Transportasi Dengan Mempertimbangkan Ability To Pay (ATP) dan Willingness To Pay (WTP) Penumpang Menuju New Yogyakarta International Airport (Studi Kasus: Kereta Api, Kendaraan Umum dan Kendaraan Pribadi). Universitas Gadjah Mada.
Sihombing, D.A. \& Surbakti, M.S., 2013. Analisa Pemilihan Moda Kereta Api dan Bus (Studi Kasus: Medan-Pematang Siantar). Jurnal Teknik Sipil USU, 2(1).

Surakarta, B.K., 2018. Kota Surakarta Dalam Angka. Surakatra : BPS Kota Surakarta.

Tamin, O.Z., Rahman, H., Kusumawati, A., Munandar, A.S. \& Setiadji, B.H., 1999. Evaluasi tarif angkutan umum dan analisis ability to pay (ATP) dan willingness to pay (WTP) di DKI Jakarta. Jurnal Transportasi, FSTPT, 1(2), pp.121139.

Tsamboulas, D., Evmorfopoulos, A.P. \& Moraiti, P., 2012. Journal of air transport management modeling airport employees commuting mode choice. Journal of Air Transport Management, 18(1), pp.74-77.

Wulansari, D.N., 2016. Kompetisi pemilihan moda angkutan penumpang berdasarkan model logit-binomial-selisih dan logit- minomialnisbah. Jurnal Fropil, 4.

Wulansari, D.N., Tamin, O.Z., Wibowo, S.S. \& Weningtyas, W., 2015. Analisis Ability To Pay (ATP) dan Willingness To Pay (WTP) Pengguna Kereta Api Bandara (Studi Kasus- Bandar Udara Internasional Soekarno-Hatta). Jurnal Forum Studi Transportasi Antar Perguruan Tinggi, Program Studi Magister Teknik Sipil, Institut Teknologi Bandung, Bandung. 
[This page is intentionally left blank] 